\title{
Aby Warburg: The Collective Memory as a Medium for Art
}

\author{
Gabriel Badea*
}

\begin{abstract}
In this paper, I intend to study the contribution of Aby Warburg, a cultural theorist and an art historian, especially his concern with the relations between memory and history, relations that have been theorized in the late 20th century, but which Warburg anticipated, to a certain degree. In his writings, there can be identified those relations that make memory a metahistorical category or an anti-historical discourse (Pierre Nora, Yosef Yerushalmi); then, his writings can be connected with those of Maurice Halbwachs, the first who approached memory as a social phenomenon. Thus, according to Warburg, collective memory can be regarded as a medium for art, which ensures the survival of images and pathos formulas even when the violence of historical development leads to a decline of the creative spirit. One might say that via a detour through the archaic (Pueblo Indian culture), Warburg managed to reduce the distances which the historical method had established to the Antiquity's vestiges (process that started in the Renaissance). His hypothesis was that the employment in the historical development of Western civilization leads to the atrophy of certain potentialities of the human spirit, which can be addressed in the anti-historicist discourse, specific to postmodernity.

In the last part of the paper, I propose to dwell on The Mnemosyne Atlas, Warburg's last project, as a visual synthesis of the research that he conducted throughout his life.
\end{abstract}

Keywords: memory, history, image, symbol, art history, pathos formulas, anachronism

\section{Introduction}

About his work and his personality, there were written many papers, mainly due to the Institute and the Library that he created and which bears his name. Rejecting the model of art history as the history of styles (Wölfflin, Riegl) or the aesthetic theory (Ruskin, Pater), the German researcher, together with the disciples and collaborators (Panofsky, Saxl, Klibansky), founded the iconographic method (a method consisting in the correlation of literary, philosophical and religious sources, on the one hand, and pictorial

** Scientific Researcher, Institute of Literary History and Theory "George Călinescu", Romanian Academy, E-mail: gabriel.g.badea@gmail.com 
image, on the other; the work of art is considered an interweaving of both sensitive and intelligible meanings, which are marked by dynamism and inscribed in the historical becoming). During the journey to the land of the Indian Pueblo in 1895, he discovered a pre-historic culture, still alive, and learned, indirectly, more about his own historical, rationalist and technical European civilization. Warburg correctly identified the contradictions within the Western civilization, some of which have remained unsolved even today.

Aby Warburg was one of the founders of the Kunstwissenschaft in the first half of the $20^{\text {th }}$ century, a discipline which proposed a more complex approach of the art phenomenon, than the historical method. The proposed approach was interdisciplinary, placing the artwork at the intersection of several plans which reflected the mentality or the spirituality of some certain historical eras: religion, philosophy, literature, all these being interpreted both subjectively (psychologically) and collectively (sociologically, anthropologically).

\section{Towards a new interpretation of art}

Warburg's favorite field of interest was the Renaissance, in which he saw an intense period of transformations of the historical spirit. During this period, he was not only interested in the history of the artwork and styles of representation, but in the life, death and rebirth of the images in a wider sense. The first approach would be in a historical sense as he investigates the possibility that some specific images of the Antiquity might have survived or might be rediscovered by the artists of the Renaissance. The second one would be an opening towards the realms that are situated in the proximity of canonic art like the technique of wax figures (voti) or that of the illustrations from the astrological treatises of the epoch ${ }^{1}$. His thesis was that even minor works reflect the mentality of a certain historical age, just like the already acknowledged works of art. In the same time, the study of minor works leads to a better understanding of canonic art, all being placed on and nourished by the same soil (the one of the collective mentality and memory), an exception being made in the case of major works of art, the synthesis realized by the author is much more elaborated. The principles of the Warburgian analysis, stated at the end of the study dedicated to Botticelli's works - The Birth of Venus and Spring ${ }^{2}$, are the following:

\footnotetext{
${ }^{1}$ Studies collected in the volume The Renewal of Pagan Antiquity: Contributions to the Cultural History of the European Renaissance (trad. engl.), Los Angeles, The Getty Research Institute for the History of Art and the Humanities, 1999. "Art of Portraiture and the Florentine Bourgeoisie", pp. 186-221; "Pagan-Antique Prophecy in Words and Images in the Age of Luther", pp. 597-667.

2 Idem, "Sandro Botticelli's Birth of Venus and Spring. An Examination of Concepts of Antiquity in the Italian Early Renaissance ”, pp. 89-156.
} 
I In autonomous, "major" art, the artistic manipulation of dynamic accessory forms evolves from an image of specific dynamic states originally perceived in reality.

II The artist's self-distancing from the true context of the object fosters the addition of "dynamic" forms; in so-called symbolic or allegorical works of art, the latter are the first to appear, because from the outset, the context of reality is eliminated, rendered "metaphorical".

III The remembered image of generalized dynamic states, through which the aperception of the new impression takes place, is later uncounsciously projected, in the work of art, as an idealizing outline.

IV Mannerism or idealism in art is only a special case of the automatic reflex of artistic imagination (Warburg 1999, 144).

First, one mention should be added: Warburg was not a theorist or a philosopher of culture, dwelling into highly general speculations, as Koerner states in his article (Koerner 2012, 96). Then, this principle quoted above should be read taking into account the works of other scholars who had a great influence on his thinking. It is known that the first museums of art appeared at the end of the $18^{\text {th }}$ century and that their systematization is made according to historical criteria; in the $19^{\text {th }}$ century, the history of art enters universities as academic disciplines. These are the two fundaments that consecrate the interpretation of the art phenomenon as a historical phenomenon first. Furthermore, within the field of art history, there are two major orientations: the first which focuses on the morphological analysis of styles and which reduces the work of art to its form, being represented by $\mathrm{H}$. Wölfflin, A. Riegl, E. Gombrich; and the second which gives a greater importance to the content of the work of art, that is analysed from a semantic point of view, being at the same time a theory of culture, represented by $\mathrm{E}$. Mâle, A. Warburg, F. Saxl, E. Panofsky. Hence Warburg finds himself among the initiators of the new iconological method, that interprets the work of art in conjunction with parallel sources such as literature and theology, identifying the presence of common motifs and themes (Sauvagnargues 1998, 20). Gradually, Warburg's name will be eclipsed by those of his collaborators (Panofsky, Gombrich) and by the increasing popularity of the institute and library that bear his name. The library consisting in a collection of more than sixty thousands volumes will be moved from Hamburg to London, because of the Nazi uprising. Warburg's contribution to the art history will be rediscovered by researchers such as Kurt Forster ${ }^{3}$, Georges Didi-Huberman ${ }^{4}$, Silvia Ferretti ${ }^{5}$ and others in the second half of the $20^{\text {th }}$ century.

\footnotetext{
3 "Aby Warburg's History of Art: Collective Memory and the Social Mediation of Images", Daedalus (Winter, 1976), pp. 169-176; "Aby Warburg: His Study of Ritual and Art on Two Continents", October, vol. 77 (Summer 1996), pp. 6-24.

4 "Aby Warburg et l'archive des intensités", in Études photographiques, no. 10, November 2001, pp. 144-168. "Artistic Survival. Panofsky vs. Warburg and the Exorcism of Impure Time”, Common Knowledge, Volume 9, Issue 2, Spring 2003, pp. 273-285. Didi-Huberman,
} 
At the beginning, his studies focused on the Renaissance, Warburg being influenced by the theories coming from different scientific fields. He studied history of art with Henry Thode and Carl Justi and during his stay in Florence, he attended August Schmarsow's seminar. A significant influence had Theodor Vischer's theory on the symbol, that Warburg used in his interpretation of culture in terms of genetic and functional. Vischer defined the symbol on two plans: the semantic sense, invariably, which works as a link between image and meaning, the first term designating a visible object, and the second, the concept, which may not be perceived in the absence of image, but whose reality or existence can be reduced due to the former. The second plan is that of historical evolution, Vischer distinguishing between the "obscure-confuse" relationship in which there is a complete identification between image and meaning just like the magical associations specific to archaic societies. To the opposite extreme, there is the connection of the logical disjunctive type, in which the two terms are opposed to each other, like in the case of allegory. From this point of view, it is worth mentioning Hegel's observation that the allegory is a frozen symbol, within which the two terms do not find each other in a communication relationship, through which they mutually intensify themselves. Vischer situates the origin of art on a intermediary plan, delimited by the two poles "where the symbol is understood as a sign and however, as an image, something remains animate, and where the soul excitement, held in tension between these two poles, does not reach its full concentration through the associative force of the metaphor so that it discharges through action, and it is not enough to dislodge so much through the dissociative order for it to seek refuge in concepts" (Wind 1931 apud Dittman 1988, 138).

Another important source for Warburg's thinking was due to Hermann Usener, a history of religions scholar, who had theorized the survival of pagan elements in the civilized societies of that time. The influence of these two, Vischer and Usener, is visible in the work A Lecture on Serpent Ritual. Reminiscences from a Journey to the Pueblo Indians (Warburg 2003), an anthropological approach written after a field research between 1895-1896. Warburg remarked the co-existence of a logical society with one of magical causality, for the fact that at the beginning of the $20^{\text {th }}$ century, efforts were being made by the Catholic Church to suppress the pagan background of the Pueblo spirituality: "They are equidistant from the magic and the logos, and their tool is the symbol that they know how to handle. Between the man who grabbs with his hand and the man who thinks, there is the man who establishes symbolic relationships"(Warburg 2003, 75-

Georges - L'Image survivante: histoire de l'art et temps des fantômes selon Aby Warburg, Paris, Éd. de Minuit, 2002.

5 "«...la fatica di ricostruire la naturale unità fra le parole e immagine». Warburg, Benjamin e ciò che la storia non può dire", in Aisthesis, no. 2/ 2010, pp. 121-131. 
76). Warburg gives importance to visual symbols (the serpent-thunder, which symbolizes the rain that fecundates the earth and favours the growth of plants on which the existence of the community depends; the symbolism of the ladder as a means of the ascension and descension in space, the serpent ring as a symbol of temporal cycles), as well as the rituals themselves, such as rain invocation, humiskatchina. It is obvious that in the case of the Pueblo civilization, one cannot speak about the existence of a historical conscience, about a discourse that could record the events from the life within the community and which might structure them according to rational principles that endow a meaning. Therefore, the following question arises: where do these symbols emerge from, symbols that govern the lives of succesive generations? The answer offered by Warburg and by other authors identifies this deposit as being the strange medium of collective memory.

It should be noted that Warburg does not quote and probably did not know the work of Maurice Halbwachs, the first author who theorized this concept. The two works quoted by Warburg are Richard Semon's Die Mneme als erhalttendes Prinzip im Wechsel des organischen Geschehens, Leipzig, 1904 and Tito Vignoli's Mito e Scienza, Milano, 1879. Due to his formation and his interest in image mediums, Warburg gave a greater importance to the iconographic area from cultural memory. Inspired by Semon's work, he spoke of a "mnemonic energy" that manifests itself in different historical eras and that is responsible for the survival (Nachleben) of certain pathos formulas (Pathosformeln), created in Antiquity in order to capture the interpenetration between spirit and matter. From this point of view, ancient gods' representations would be the instrument to represent the full range of pathos formulas. Warburg said that if the statuary group Laocoon had not have been accidentally discovered during the Renaissance (1506), it would have had to be reinvented because the spirit of that era had reached the level of synthesis between life and art, enabling this achievement. So, cultural memory is the medium which assures the survival of images and pathos formulas given the erosion and violence that characterize the historical dimension. From this point of view, it should be noted that cultural memory exists in parallel with the historical development. Jan Assmann argues that cultural memory is based on certain fixed points, which he calls "figures of memory":

Cultural memory has its fixed points; its horizon does not change with the passing of time. These fixed points are fateful events of the past, whose memory is maintained through cultural formations (texts, rites, monuments) and institutional communication (recitation, practice, observance).[...] In the flow of everyday communication such festivals, rites, epics, poems, images, etc., form «islands of time», islands of a completely different temporality suspended in time (Assmann 1995, 129). 
Regarding Warburg's contribution to the cultural memory's matter, Assman quotes the formula "memory spaces of retrospective contemplativeness", and also the fact that the German scholar "ascribed a type of «mnemonic energy» to the objectivation of culture, pointing not only to the works of high art, but also to posters, postage stamps, costumes, customs, etc. (Assmann 1995, 129). Moreover, another important concept for Warburg's thinking was that of Denkraum (thought-space), discovered during his journey in Arizona and New Mexico: "Mythical and symbolic thinking strive to form spiritual bonds between humanity and the surrounding world, shaping distance into the space required for devotion and reflection: the distance undone by the instantaneous electric connection" (Warburg 2003, 133). These lines are not written from the perspective of a critic of modernity, but rather of an interpreter who tries to distinguish the tensions and dialectical oppositions that underlie the founding and functioning of the human culture. The landmarks of his thinking were the oppositions between static and dynamic, Apollinian and Dionysian, realism and idealism. Although he was inspired by Nietzsche's Birth of Tragedy, particularly in his Renaissance studies, Warburg did not share his pessimism on modern culture: "In contrast with Nietzsche, for whom the loss of the Dionysian heralded the birth of modern, scientific, Socratic culture, the transformation signifies for Warburg a growth of aesthetic creativity. The distance of the sign from its object indicates the intervention of human artifice, as it had been implied in Warburg's study of the intermezzi and early opera" (Rampley 1997, 52).

Warburg rejected the traditional way in which the history of art was written, as well as the aesthetic way in which "primitive" art was considered inferior in relation to the rationalized and intellectualized art specific to "civilized" countries. Following the connection between the archaic and modern man, wondering where the missing link is, Warburg discovered a Renaissance that cultivated the irrational and pagan mysteries, a Renaissance absent from the History of Art until then. He became known mainly due to his studies in this new direction, some continued by his disciples, but his position on the contradictions of modernity remained less known. The foundations of his method have been synthesized by researchers such as Georges Didi-Huberman or Giorgio Agamben. After the second, the novelty brought by the method proposed by Warburg consisted that "on the basis of a study of literary sources and an examination of cultural tradition [...] to have displaced the focal point of research from the study of styles and aesthetic judgment to the programmatic and iconographic aspects of the artwork"

Mircea Eliade also wrote extensively about metahistorical and unconscious mental structures, such as the myth of the Eternal Return, beliefs

\footnotetext{
${ }^{6}$ G.Agamben, "Warburg and the Nameless Science", in Potentialities. Collected Essays in Philosophy, Stanford, Stanford University Press, 1999, p. 89.
} 
in the cyclical nature of time, the myth of the Golden Age, and so on. Eliade has a wider historical and cultural openness than Warburg, which focuses on the ancient Greco-Roman universe and its resurrection during the Renaissance (with the exception of the foray into the universe of beliefs and symbols of the Pueblo Indians). Both were supporters of an interdisciplinary approach, going beyond the limits of their own field and following the manifestations of the human spirit in other neighboring fields ${ }^{5}$. Warburg rejected the interpretation of works of art from Antiquity or the Renaissance by placing them in a specific modern way of thinking, by breaking the organic links between the work and the universe of beliefs and symbols of that era. He considered that the cultural memory that the artist possesses in his time can provide essential elements for an adequate interpretation of the work of art. Conversely, through the work of art, we can have access to the forms of spirituality specific to a certain era, forms that most often have come down to us only "encrypted" in this way. He foresaw a necessary connection between the field of art history and that of religion: "May the history of art and the study of religion - between which lies nothing at present but wasteland overgrown with verbiage - meet each other one day in learned and lucid minds [...] and may they share a workbench in the laboratory of the iconological science of civilization" $"$.

But there is also a major difference between Warburg and Eliade: the former is a follower of cultural evolutionism; its concepts, such as engram or pathosformel, have a historical existence and undergo significant transformations over time. Giorgio Agamben remarked that Jung's name does not appear among Warburg's notes, explaining the absence by the fact that Jung's unconscious archetypes are metahistorical, unlike Warburg's engrams $^{8}$. In highlighting those universal and metahistorical mental structures, Eliade is obviously closer to Jung and outside the evolutionary paradigm.

On another level, Aby Warburg believed that the history of art must make the connection between the past and the present of humanity, not to isolate itself in the socio-historical conditions of the present.

\section{The Mnemosyne Atlas}

Now it could be brought in discussion Warburg's major study from the last years of his life, The Mnemosyne Atlas, made between 1924-1928. The Atlas brings together more than a thousand images (reproductions from

\footnotetext{
${ }^{7}$ A.Warburg, The Renewal..., pp. 650-651.

${ }^{8}$ G. Agamben, op.cit., p. 95, n. 22.
} 
books, magazines, newspapers), which are grouped thematically and arranged on seventy-nine panels. The Atlas's title refers to the ancient name of the goddess of memory and mother of the nine muses, and the choice is very relevant for Warburg's position against the historicism's hegemony as a philosophy of history. The appeal to memory's theme is evident, primarily due to the chosen title; secondly, the fact that the structuring principle of the Atlas is thematical, without taking into account a certain chronology, nor an affiliation to a particular period in the history of culture, nor a certain hierarchy in terms of stylistic evolution. Thus, cultural memory is a homogeneous medium that knows no tensions and no oppositions that mark the evolution of the historical process. From this matrix, the emblem-images for certain categories of the human spirit recur periodically, the panels' order being the following:

1. panels A, B, C: cosmological-genealogical prologue

2. panels 1, 2, 3: classical cosmology

3. panels 4, 5, 6, 7, 8: classical "pre-stamping" of artistic "expressive values"

4. panels 20,21, 22, 23, 23a, 24, 25, 26, 27, 28-29: transmission and degradation of Greek

astronomical thought in Hellenistic, medieval Arabic, medieval and Renaissance European

astrological imagery

5. panels 30, 31, 32, 33, 34, 35, 36, 37, 38, 39, 40, 41, 41a, 42, 43, 44, 45, $46,47,48,49$ : the

"afterlife" of classical "expressive values" in Renaissance, mainly late quattrocento art

6. panels 50-51, 52, 53, 54, 55, 56: "inversion," ascent, and descent in Renaissance, mainly cinquecento art through Manet

7. panels 57, 58, 59, 60, 61-64: Virgil, Dürer, Rubens, and the northward translatio

8. panels 70, 71, 72, 73, 74, 75: Baroque excess and Rembrandt's mediation of the same

9. panels 76, 77, 78, 79: final "inversions": advertisement and transubstantiation (Johnson 2012, 11-12)

For a better understanding of the principles that led to the composition of Atlas, I will appeal to the works of a contemporary researcher as long as Warburg did not have the necessary time to put his ideas into a theoretical system. In his studies concerning Warburg's thought, Georges Didi-Huberman stopped on the concept of images' survival (Nachleben) that, according to his interpretation, captures the complex temporality of images, the fact that they often appear as a phenomenon of anachronism in relation to the historical evolution of a particular society. Therefore, they fall into a temporality defined by longues durées and «time crevasses», latencies and 
symptoms, concealing memories and arising memories, anachronisms and critical thresholds" (Didi-Huberman 2000, 50). Warburg's merit remains that he refused the theoretical model of art history, which viewed image as a point on an oriented line from the past to the present, or as an aspect of the eternal engraved in the historical development; instead, he "transformed image into a vital question, alive and highly complex: a real sensitive centre, the dialectic and ideal ankle of the «historical life» in general" (Ibidem, 51-52). This polarity of the image, designed by Warburg, means that it does not produce "historicity but anachronic historicity and no signification but symptomatic signification" (Ibidem, 91), so that even less stylized or poorer images from the aesthetic point of view could witness the longue durée's presence.

\section{The relation memory/history in Pierre Nora's work}

Unlike Warburg, the French researcher Pierre Nora approached the relationship between memory and history focusing on three aspects of memory, i.e. material, symbolic and functional. Each of these three directions has been studied in relation to historiographical discourse (the history of history) in the case of the sites of memory. The latter are understood as places of condensation of "history-memory" and their existence is mainly due to the decline of the living memory, and to the inadequacy of memory and history in the case of contemporary societies (Nora 1984, XVIII-XLII). Therefore, although Nora's arguments are inscribed on other reference planes and follow other goals, like Warburg, he also notices the gap between neutral experience and lived experience (cf. German Erfahrung/ Erlebnis) in the context of modernity, where every experience is mediated and directed by the historicist pattern (or the technical-aestheticized one, after Warburg).

Memory and history are two types of discourses about the past, about the history of a community, a culture, a civilization or even the past of all humanity. Although until recently, they have not been considered opposites, Pierre Nora, a coordinator of the collective volumes „Les Lieux de memoire” starts from this fundamental thesis. Memory was evacuated by historical discourse, and as a consequence, we have places of memory because we have no means of memory. If we still live in our memory, there would be no need to consecrate separate places. In his work, Cosmos and History. The Myth of the Eternal Return, Eliade showed the ways through which the personalities whose existence was attested historically, transformed themselves into mythical beings at a distance of only a few generations (Eliade 1959, 38-48). In respect to this collective memory, Nora says that it has disappeared while the whole mosaic of cultures around the world have entered into historicity: "ethnological societies awakened from their sleep by a colonial rape".

Further evidence of the fact that the two concepts are competing is that Nora speaks about the historization of the memory and the figure of "the 
memory captured by history", having three symptoms in the context of modern societies:

a) reign of the archive;

b) a final conversion of memory into individual psychology;

c) memory-distance, the progressive break away of past to the present, by sealing one to another.

From another research field, the history of ideas and medieval literature, Mary Carruthers, in the Preface to her work The Book of Memory: A Study of Memory in the Medieval Culture states: "the culture of the Middle Ages was fundamentally one memorial in the same way that contemporary culture of the West is a documentary one" (Carruthers 2008, 9).

\section{Conclusions}

In the present paper, I intended to present Aby Warburg's contribution to the interpretation of the image across multiple reference plans, according to a newly created method (iconography), which produces an enrichment of meaning, a densification of its significance, thus avoiding the impoverishment of the content, resulting from a too hasty inclusion on a temporal axis, according to the historical method. Thus, Warburg makes a synthesis between the two major directions of the aesthetic thought during the $19^{\text {th }}$ century, the psychological one and the historical-phenomenological one. Meanwhile, he also gave a special importance to the role of collective memory in this survival of the images, which characterized it as anachronistic and symptomatic. But he did not interpret memory as a social fact, as Maurice Halbwachs did later, putting it in relation to other concepts, such as identity, role, group, community. His interpretation is consonant with the relatively recent theories in the last forty years, concerning cultural memory as a meta-historical category, which tends to replace the hegemonic and authoritarian discourse of the historical type.

\section{Bibliography:}

Agamben, Giorgio, "Warburg and the Nameless Science", in Potentialities. Collected Essays in Philosophy, Stanford, Stanford University Press, 1999, pp. 89-103.

Assmann, Jan, "Collective Memory and Cultural Identity", New German Critique, no. 65, Spring-Summer, 1995, pp. 125-133.

Carruthers, Mary, The Book of Memory: A Study of Memory in the Medieval Culture, Cambridge, Cambridge University Press, 2008.

Didi-Huberman, Georges, Devant le temps. Histoire de l'art et anachronisme des images, Paris, Les Éditions de Minuit, 2000.

- , „Aby Warburg et l'archive des intensités”, in Études photographiques, no. 10, novembre 2001, pp. 144-168. 
- , „Artistic Survival. Panofsky vs. Warburg and the Exorcism of Impure Time”, Common Kowledge, Volume 9, Issue 2, Spring 2003, pp. 273-285.

Dittmann, Lorenz, Stil, simbol, structură, [Style, Symbol, Structure], București, Ed. Meridiane, 1988.

Eliade, Mircea, Cosmos and History, The Myth of the Eternal Return, New York, Harper, 1959.

Ferretti, Silvia, "«...la fatica di ricostruire la naturale unità fra le parole e immagine». Warburg, Benjamin e ciò che la storia non può dire", in Aisthesis, no. 2/ 2010, pp. 121-131.

Forster, Kurt, "Aby Warburg's History of Art: Collective Memory and the Social Mediation of Images", Daedalus (Winter, 1976), pp. 169-176.

- , "Aby Warburg: His Study of Ritual and Art on Two Continents", October, vol. 77 (Summer 1996), pp. 6-24.

Johnson, Cristopher, Memory, Metaphor, and Aby Warburg's Atlas of Images, Ithaca/New York, Cornell University Press, 2012.

Koerner, Joseph Leo, "Writing Rituals. The Case of Aby Warburg", Common Knowledge, 18, 1, 2012, pp. 86-105.

Nora, Pierre, "Entre Mémoire et Histoire", p. XVIII - XLII, in Nora, Pierre (coord.) - Les lieux de la mémoire, vol. I. La République, Paris, Gallimard, 1984.

Rampley, Matthew, "From Symbol to Allegory: Aby Warburg's Theory of Art", Art Bulletin, March 1997, Volume LXXIX, Number 1, pp. 41-55.

Sauvagnargues, Anne, „Le probleme de l'histoire de l'art”, in Art et philosophie (Textes reunis par Anne Sauvagnargues), Fontenay/ Saint-Cloud: Feuillets de l'ENS Fontenay/ Saint-Cloud, 1998.

Warburg, Aby, The Renewal of Pagan Antiquity: Contributions to the Cultural History of the European Renaissance, Los Angeles, The Getty Research Institute for the History of Art and the Humanities, 1999.

Warburg, Aby, Le Rituel du serpent. Récit d'un voyage en pays pueblo, Paris, Macula, 2003.

Wind, Edgar, „Warburgs Begriff der Kulturwissenschaft und seine Bedeutung für die Ästhetik", in Zeitschrift für Ästhetik und allgemeine Kunstwissenschaft, 25, 1931, pp. 163179. 